\title{
Interaction between an oxygen and an alkynyl-carbon atom in 1-(2-nitrophenyl)-4-phenylbutadiyne
}

\author{
H. S. Bengaard, S. Larsen, H. O. Sørensen, K. J. Robinson and J. D. Wallis
}

Acta Cryst. (1999). C55, 106-108

Copyright (C) International Union of Crystallography

Author(s) of this paper may load this reprint on their own web site or institutional repository provided that this cover page is retained. Republication of this article or its storage in electronic databases other than as specified above is not permitted without prior permission in writing from the IUCr.

For further information see http://journals.iucr.org/services/authorrights.html

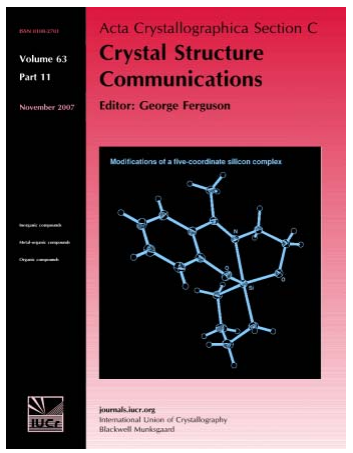

Acta Crystallographica Section C: Crystal Structure Communications specializes in the rapid dissemination of high-quality studies of crystal and molecular structures of interest in fields such as chemistry, biochemistry, mineralogy, pharmacology, physics and materials science. The numerical and text descriptions of each structure are submitted to the journal electronically as a Crystallographic Information File (CIF) and are checked and typeset automatically prior to peer review. The journal is well known for its high standards of structural reliability and presentation. Section $C$ publishes approximately 1000 structures per year; readers have access to an archive that includes high-quality structural data for over 10000 compounds.

Crystallography Journals Online is available from journals.iucr.org 
Guelzim, A., Khrifi, S. \& Baert, F. (1993). Acta Cryst. C49. 21212124.

North, A. C. T., Phillips, D. C. \& Mathews, F. S. (1968). Acta Cryst. A24, 351-359.

Perrin, M. \& Oehler, D. (1991). Conformations of Calixarenes in the Crystalline State in Calixarenes: A Versatile Class of Macrocyclic Compounds, edited by J. Vicens \& V. Böhmer. Dordrecht: Kluwer.

Sheldrick, G. M. (1997a). SHELXS97. Program for the Solution of Crystal Structures. University of Göttingen, Germany.

Sheldrick, G. M. (1997b). SHELXL97. Program for the Refinement of Crystal Structures. University of Göttingen, Germany.

Acta Cryst. (1999). C55, 106-108

\section{Interaction between an oxygen and an alkynyl-carbon atom in 1-(2-nitrophenyl)-4- phenylbutadiyne}

Hanne Skov Bengaard, ${ }^{a}$ Sine Larsen, ${ }^{a}$ Henning Osholm SøRensen, ${ }^{a}$ Kathryn J. Robinson ${ }^{b}$ and John D. WALLIS $^{b}$

${ }^{a}$ Centre for Crystallographic Studies, Department of Chemistry, University of Copenhagen, Universitetsparken 5, DK-2100 Copenhagen, Denmark, and ${ }^{b}$ Centre for Materials Research, School of Physical Sciences, University of Kent, Canterbury CT2 7NH, England. E-mail: jdw@ukc.ac.uk

(Received 16 July 1998; accepted 14 August 1998)

\begin{abstract}
The title compound, $\mathrm{C}_{16} \mathrm{H}_{9} \mathrm{NO}_{2}$, studied at $122 \mathrm{~K}$ shows a short 1,5 interaction between a nitro-O atom and an alkynyl-C atom. The atomic separation is $2.636(2) \AA$, and the dialkyne group is bent from linearity at this $\mathrm{C}$ atom only.
\end{abstract}

\section{Comment}

The study of the molecular distortions induced by placing a nucleophilic functional group close to an electrophilic functional group in the same molecule has given insight into the early stages of reaction coordinates (Bürgi \& Dunitz, 1994). For example, in perisubstituted naphthalenes bearing a dimethylamino group and a carbonyl-containing functional group, the 1,5 interaction between the amino- $\mathrm{N}$ atom and carbonyl-C atom models an early stage in the addition of a nucleophile to the carbonyl bond and small pyramidalizations of the carbonyl-C atom's bonding geometry are observed (Schweizer et al., 1978). We have been investigating interactions involving alkyne groups (Pilkington et al., 1995). 1,5 interactions between nitro-O atoms and alkynyl-C atoms have been observed in (I) and (II), both of which show trans distortions of the triple bonds, as shown in the structural formulae (Rice \& Wallis, 1993; Pilkington et al., 1996). Analysis of the results of $a b$ initio calculations on (II) using Bader's theory of atoms in molecules (Bader, 1990) gives evidence of a weak bonding interaction between the nitro-O and alkynylC atoms (Pilkington et al., 1996). These interactions may be interpreted as representing the structural consequences of an incipient Michael addition reaction. The structure of the title compound (III), which contains a dialkyne rather than an alkyne group, was determined to extend this investigation.

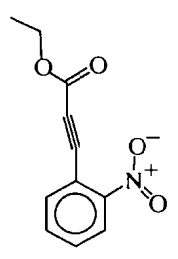

(I)

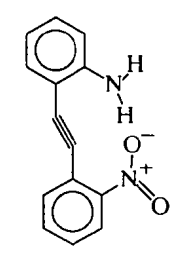

(II)

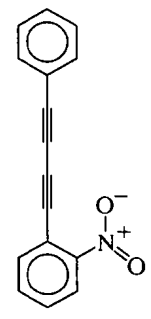

(III)
The overall structure is almost planar, and the interplanar angle between the nitro group and the attached aromatic ring is only $9.93(16)^{\circ}$. As in (I) and (II) there is a short 1,5 contact between a nitro-O atom and the closest $\mathrm{C}$ atom of the dialkyne group. The distance between these atoms is $2.636(2) \mathrm{A}$, and is very similar to those in (I) [2.642(2) $\mathrm{A}]$ and (II) [2.662 (4) and 2.772 (4) $\AA$ ]. The dialkyne group deviates from linearity by $7.28(13)^{\circ}$ at the $\mathrm{C}$ atom involved in the interaction such that this $\mathrm{C}$ atom is displaced from the vector connecting its two neighbours towards the $\mathrm{O}$ atom. However, unlike the structures of (I) and (II), there is no significant deviation from linearity at any of the other three $\mathrm{Cs} p$ atoms, where the bond angles lie in the range 178.60 (13) to $179.43(13)^{\circ}$. There is no difference in the bond lengths of the two alkyne groups [1.203(2) $\AA$ ]. Furthermore, the structure contains no unusually short intermolecular contacts.

In structures (I) and (II), the bending induced at the alkyne-C atom not directly involved in the interaction is interpreted as being due to the start of the development of in-plane $s p^{2}$ lone-pair electron density as a result of the incipient nucleophilic addition to the other end of the triple bond. In (III), this feature need not be so localized since the developing lone-pair electron density would be able to conjugate with the $\pi$ system of the second triple bond. This would account for the absence of a second bend in the dialkyne group. Alternatively, it could be argued that only a single bend is required to minimize repulsion between the two groups and, in particular, to increase the distance between $\mathrm{Ol}$ and the second alkyne-C atom, C2, to 3.201 (2) $\AA$. However, if repulsive interactions were operating at ca $3.0 \AA$, it would have been expected that the nitro group would have rotated 
out of coplanarity with the molecule to relieve the much shorter, and presumably more repulsive, $\mathrm{O} 1 \cdots \mathrm{Cl}$ contact. In fact, the ortho substituents are splayed apart in the plane of the molecule, but this only indicates that the $\mathrm{O} 1 \cdots \mathrm{Cl}$ interaction is repulsive at separations below 2.636 (2) $\AA$.

Four known dialkyne structures which contain intramolecular 1,5 O . Csp contacts show longer $\mathrm{O} \cdots \mathrm{C}$ distances (2.81-2.98 $\AA$ ) than in (III), and no pronounced bending at the involved Csp atom (Hanson, 1975; Lu et al., 1993; Bott et al., 1995; Kane et al., 1995). In each case the $\mathrm{O}$ atom involved belongs to a carbonyl group.

A search of the Cambridge Structural Database (Allen et al., 1991) revealed that dialkyne groups in acyclic molecular fragments are usually close to linear; of 117 hits $(R<10 \%$, no errors or disorder) $68 \%$ show angular deviations at the alkyne-C atoms of no more than $4^{\circ}$. Some of the larger angular distortions (of up to $10^{\circ}$ at the termini of the dialkyne moiety) are observed in Toda's clathrates of 1,6-bis(2-chlorophenyl)1,6-diphenylbuta-2,4-diyn-1,6-diol. They are associated with $1,5 \mathrm{Cl}$... Csp contacts of $c a 3.1 \AA$ [e.g. GIMKIW (Kaftory et al., 1988) and VAXFUV (Toda et al., 1989)]. When restrained in a cyclic structure, a dialkyne group can be bent by up to $15^{\circ}$ from linearity at any one $\mathrm{C}$ atom [e.g. FECDAS (Kaftory et al., 1987) and PECBAA (Anthony et al., 1993)].

It is important to recognize that a final conclusion about the type of nitro/dialkyne interaction observed in (III) can only be made from a series of structures, since the crystal packing arrangement could be responsible for small distortions to a particular molecular structure.

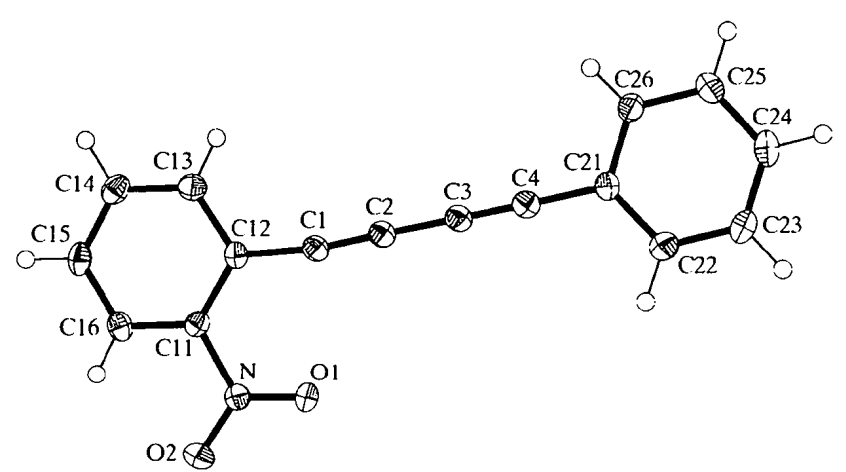

Fig. 1. ORTEPIII (Johnson \& Burnett, 1996) drawing of the title compound. Anisotropic displacement parameters are drawn at the $50 \%$ level for non- $\mathrm{H}$ atoms and circles of an arbitrary radius depict $\mathrm{H}$ atoms.

\section{Experimental}

Substance (III) was prepared by the coupling of ethynylbenzene with 1-bromoethynyl-2-nitrobenzene using a copper(I) chloride catalyst and hydroxylamine hydrochloride in ethanolic ethylamine, as described for other cases (Tsibouklis et al., 1988); m.p. $433 \mathrm{~K},{ }^{1} \mathrm{H}$ NMR $\left(270 \mathrm{MHz}, \mathrm{CDCl}_{3}\right): 8.13$ $\left(1 \mathrm{H}, d d, J 8.1,1.3,3^{\prime}-\mathrm{H}\right), 7.74\left(1 \mathrm{H}, d d, J 7.7,1.6,6^{\prime}-\mathrm{H}\right)$, $7.61\left(1 \mathrm{H}, d t, J 7.5,1.3,5^{\prime}-\mathrm{H}\right), 7.56\left(2 \mathrm{H}, d d, J 7.9,1.7,2^{\prime \prime}-\right.$ $\left.6^{\prime \prime}-\mathrm{H}\right), 7.51\left(1 \mathrm{H}, d t, J 7.7,1.5,4^{\prime}-\mathrm{H}\right), 7.38$ p.p.m. $(3 \mathrm{H}, m$, $\left.3^{\prime \prime}-, 4^{\prime \prime}-, 5^{\prime \prime}-\mathrm{H}\right),{ }^{13} \mathrm{C}$ NMR $\left(67.8 \mathrm{MHz} \mathrm{CDCl}_{3}\right): 150.1\left(2^{\prime}-\mathrm{C}\right)$, $135.9\left(5^{\prime}-\mathrm{C}\right), 133.0\left(6^{\prime}-\mathrm{C}\right), 132.7\left(2^{\prime \prime}-, 6^{\prime \prime}-\mathrm{C}\right), 129.7\left(4^{\prime}-\mathrm{C}\right)$, $129.3\left(4^{\prime \prime}-\mathrm{C}\right), 128.5\left(3^{\prime \prime}-, 5^{\prime \prime}-\mathrm{C}\right), 125.0\left(3^{\prime}-\mathrm{C}\right), 121.3\left(1^{\prime \prime}-\mathrm{C}\right)$, $117.8\left(1^{\prime}-\mathrm{C}\right), 84.9,81.6,76.1,73.7$ p.p.m. (1-, 2-, 3-, 4-C).

\section{Crystal data}

$\mathrm{C}_{16} \mathrm{H}_{9} \mathrm{NO}_{2}$

$M_{r}=247.24$

Orthorhombic

Pbca

$a=7.532(5) \AA$

$b=13.278(2) \AA$

$c=23.7103(10) \AA$

$V=2371.3(16) \AA^{3}$

$Z=8$

$D_{x}=1.385 \mathrm{Mg} \mathrm{m}^{-3}$

(at $122 \mathrm{~K}$ )

$D_{m}=1.305 \mathrm{Mg} \mathrm{m}^{-3}$

(measured at $295 \mathrm{~K}$ )

$D_{m}$ measured by flotation in aqueous $\mathrm{KI}$

\section{Data collection}

Enraf-Nonius CAD-4 diffractometer

$\omega-2 \theta$ scans

Absorption correction: none

6580 measured reflections

2404 independent reflections

2249 reflections with

$$
I>2 \sigma(I)
$$

\section{Refinement}

Refinement on $F^{2}$

$R\left[F^{2}>2 \sigma\left(F^{2}\right)\right]=0.036$

$w R\left(F^{2}\right)=0.089$

$S=3.456$

2404 reflections

209 parameters

$\mathrm{H}$ atoms were refined freely

with individual isotropic

displacement parameters

$w=1 /\left[\sigma^{2}\left(F_{o}^{2}\right)\right]$
$\mathrm{Cu} K \alpha$ radiation

$\lambda=1.54180 \AA$

Cell parameters from 20 reflections

$\theta=35.47-43.19^{\circ}$

$\mu=0.751 \mathrm{~mm}^{-1}$

$T=122.0(5) \mathrm{K}$

Block

$0.38 \times 0.38 \times 0.17 \mathrm{~mm}$

Orange
Table 1. Selected geometric parameters $\left(\AA{ }^{\circ}{ }^{\circ}\right)$

$\begin{array}{llll}\mathrm{O} 1-\mathrm{N} & 1.2207(14) & \mathrm{C} 4-\mathrm{C} 21 & 1.430(2) \\ \mathrm{O} 2-\mathrm{N} & 1.2352(14) & \mathrm{C} 11-\mathrm{C} 16 & 1.388(2) \\ \mathrm{N}-\mathrm{C} 11 & 1.467(2) & \mathrm{C} 11-\mathrm{C} 12 & 1.399(2) \\ \mathrm{C} 1-\mathrm{C} 2 & 1.203(2) & \mathrm{C} 12-\mathrm{C} 13 & 1.409(2) \\ \mathrm{Cl}-\mathrm{C} 12 & 1.428(2) & \mathrm{C} 13-\mathrm{Cl} & 1.381(2) \\ \mathrm{C} 2-\mathrm{C} 3 & 1.371(2) & \mathrm{C} 14-\mathrm{C} 15 & 1.388(2) \\ \mathrm{C} 3-\mathrm{C} 4 & 1.203(2) & \mathrm{C} 15-\mathrm{C} 16 & 1.383(2) \\ \mathrm{O} 1-\mathrm{N}-\mathrm{O} 2 & 122.93(11) & \mathrm{C} 12-\mathrm{C} 11-\mathrm{N} & 120.54(11) \\ \mathrm{O} 1-\mathrm{N}-\mathrm{C} 11 & 118.98(10) & \mathrm{C} 11-\mathrm{C} 12-\mathrm{C} 13 & 116.57(11) \\ \mathrm{O} 2-\mathrm{N}-\mathrm{C} 11 & 118.09(11) & \mathrm{C} 11-\mathrm{C} 12-\mathrm{Cl} & 125.38(12) \\ \mathrm{C} 2-\mathrm{C} 1-\mathrm{C} 12 & 172.72(13) & \mathrm{C} 13-\mathrm{C} 12-\mathrm{C} 1 & 118.03(11) \\ \mathrm{Cl}-\mathrm{C} 2-\mathrm{C} 3 & 179.27(14) & \mathrm{C} 14-\mathrm{C} 13-\mathrm{C} 12 & 121.35(12) \\ \mathrm{C} 4-\mathrm{C} 3-\mathrm{C} 2 & 179.43(13) & \mathrm{C} 13-\mathrm{C} 14-\mathrm{C} 15 & 120.45(12) \\ \mathrm{C} 3-\mathrm{C} 4-\mathrm{C} 21 & 178.60(13) & \mathrm{C} 16-\mathrm{C} 15-\mathrm{C} 14 & 119.79(12) \\ \mathrm{C} 16-\mathrm{C} 11-\mathrm{C} 12 & 122.39(12) & \mathrm{C} 15-\mathrm{C} 16-\mathrm{C} 11 & 119.43(12) \\ \mathrm{C} 16-\mathrm{C} 11-\mathrm{N} & 117.06(11) & & \end{array}$

$(\Delta / \sigma)_{\max }=0.017$

$\Delta \rho_{\max }=0.246{\mathrm{e} \AA^{-3}}^{-3}$

$\Delta \rho_{\min }=-0.236{\mathrm{e} \AA^{-3}}^{-3}$

Extinction correction: SHELXL93

Extinction coefficient: $0.0041(3)$

Scattering factors from International Tables for Crystallography (Vol. C) 
The structure was solved using direct methods and refined by the full-matrix least-squares technique. All non-H atoms were refined with anisotropic displacement parameters. Weights calculated from counting statistics were employed as it was found that they provided a reliable estimate of the experimental error. The resulting averaged values of $w(\Delta F)^{2}$ as a function of $\sin \theta$ and $F^{2}$ did not show any significant variations.

Data collection: CAD-4 EXPRESS (Enraf-Nonius, 1994). Cell refinement: $C A D-4$ EXPRESS. Data reduction: DREADD (Blessing, 1987). Program(s) used to solve structure: SHELXS86 (Sheldrick, 1990). Program(s) used to refine structure: SHELXL93 (Sheldrick, 1993). Molecular graphics: ORTEPIII (Johnson \& Burnett, 1996).

We thank $\mathrm{Mr}$ Flemming Hansen for help with the crystallographic experiment.

Supplementary data for this paper are available from the $\mathrm{IUC}_{\mathrm{r}}$ electronic archives (Reference: LN1068). Services for accessing these data are described at the back of the journal.

\section{References}

Allen, F. H., Davies, J. E., Galloy, J. J., Johnson, O., Kennard, O., Macrae, C. F., Mitchell, E. M., Mitchell, G. F., Smith, J. M. \& Watson, D. G. (1991). J. Chem. Inf. Comput. Sci. 31, 187-204.

Anthony, J., Knobler, C. B. \& Diederich, F. (1993). Angew: Chem. Int. Ed. Engl. 32, 406-409.

Bader, R. F. W. (1990). Atoms in Molecules: A Quantum Theory: Oxford: Oxford University Press.

Blessing, R. H. (1987). Crystallogr. Rev. 1, 3-58.

Bott, S. G., Marchand, A. P., Talafuse, L. K. \& Rajagopal, D. (1995). J. Chem. Cryst. 25, 543-547.

Bürgi, H. B. \& Dunitz, J. D. (1994). Structure Correlation. Weinheim: $\mathrm{VCH}$.

Enraf-Nonius (1994). CAD-4 EXPRESS. Version 5.1/1.2. EnrafNonius, Delft, The Netherlands.

Hanson, A. W. (1975). Acta Cryst. B31, 831-834.

Johnson, C. K. \& Burnett, M. N. (1996). ORTEPIII. Report ORNL6895. Oak Ridge National Laboratory, Tennessee, USA.

Kaftory, M., Agmon, I., Ladika, M. \& Stang, P. J. (1987). J. Am. Chem. Soc. 109, 782-787.

Kaftory, M., Yagi, M., Tanaka, K. \& Toda, F. (1988). J. Org. Chem 53, 4391-4393.

Kane, J. J., Liao, R.-F., Lauher, J. W. \& Fowler, F. W. (1995). J. Am Chem. Soc. 117, 12003-12004.

Lu, T., Menelaou, M. A., Vargas, D., Fronczek, F. R. \& Fischer, N. H. (1993). Phytochem. 32, 1483-1488.

Pilkington, M., Wallis, J. D. \& Larsen, S. (1995). J. Chem. Soc. Chem. Commun. pp. 1499-1500.

Pilkington, M., Wallis, J. D., Smith, G. T. \& Howard, J. A. K. (1996). J. Chem. Soc. Perkin Trans. 2, pp. 1849-1854.

Rice, C. R. \& Wallis, J. D. (1993). J. Chem. Soc. Chem. Commun. pp. 572-574.

Schweizer, W. B., Procter, G., Kaftory, M. \& Dunitz, J. D. (1978). Helv. Chim. Acta, 61, 2783-2808.

Sheldrick, G. M. (1990). Acta Cryst. A46, 467-473.

Sheldrick, G. M. (1993). SHELXL93. Program for the Refinement of Crystal Structures. University of Göttingen, Germany.

Toda, F., Tanaka, K. \& Mak, T. C. W. (1989). Chem. Lett. pp. 13291330.

Tsibouklis, J., Werninck, A. R., Shand, A. J. \& Milburn, G. H. W. (1988). Chemtronics, 3, 211-214.

(C) 1999 International Union of Crystallography

Printed in Great Britain - all rights reserved
Acta Cryst. (1999). C55, 108-110

\section{1,3,5-Tris(cyanomethyl)-2,4,6-triethyl- benzene}

\author{
Christian Walsdorff, KI-MIN PaRk, Jinho OH AND \\ KIMOON KIM
}

Department of Chemistry and National Creative Research Initiative Centre for Smart Supramolecules, Pohang

University of Science and Technology, San 31, Hyojadong, Pohang 790-784, Republic of Korea. E-mail: kkim@vision. postech.ac.kr

(Received 6 August 1998; accepted 9 September 1998)

\section{Abstract}

The title compound (2,4,6-triethyl-1,3,5-benzenetriacetonitrile, $\mathrm{C}_{18} \mathrm{H}_{21} \mathrm{~N}_{3}$ ) exhibits an unexpected conformation with all the substituents, except one cyanomethyl group, pointing to the same side of the plane of the benzene ring.

\section{Comment}

Hexa-substituted derivatives of benzene with the substituents connected via methylene groups to the central benzene ring have attracted considerable interest. In general, the most stable conformation of such compounds is the one with the substituents pointing alternately to both sides (above and below) of the plane of the central benzene ring. This conformational preference has been employed in an approach to 'hexa-host' clathrate compounds (MacNicol \& Downing, 1996). More recently, derivatives with ethyl groups in the 1, 3 and 5 positions and substituents that carry functional groups attached to the remaining positions of the benzene ring have been used as predisposed (Stack et al., 1993; Walsdorff et al., 1996; Metzger et al., 1997) or preorganized (Walsdorff et al., 1997) tripodal ligands, in a self-directed macrocyclization (Bisson et al., 1997) and in the spontaneous self-assembly of a cage compound (Hartshorn \& Steel, 1997). In the course of our ongoing research on such molecules we have determined the crystal structure of the title compound, (I).

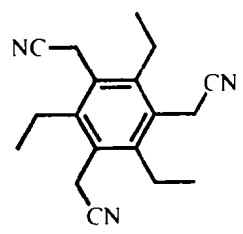

(I)

In spite of its symmetrical constitution, (I) crystallizes on a general position in the triclinic space group ISSN 0108-2701@1999 